
www.globaljournalseries.com, Email: globaljournalseries@gmail.com

\title{
RURAL DWELLERS INVOLVEMENT IN SMALL SCALE POULTRY FARMING IN OLUYOLE LOCAL GOVERNMENT AREA OF OYO STATE, NIGERIA
}

\author{
OGUNWALE O. G., ABEGUNRIN O. O., OYEWOLE O. O., OLATUNJI B.T AND AJANAKU A. O
}

(Received 1 February 2021; Revision Accepted 27 March 2021)

\begin{abstract}
Poultry production at all levels appears to be lucrative and profitable but many factors appear to limit the involvement of rural dwellers in this sector. This study was carried out at Oluyole Local Government Area Oyo State to assess the level of involvement of rural dwellers in small scale poultry farming. Some parts of Oluyole local government were purposely selected for this study because of higher concentration of rural dwellers that are involved in poultry production. A total of ninety five respondents were sampled and had a well-structured questionnaire administered to them to determine their socio economics characteristic, their level of involvement, benefit derived and constraint faced in poultry farming. Data were analyzed using descriptive statistics of frequency counts, percentage and means, Chisquare and Pearson Product Moment Correlation (PPMC) at $0.05 \%$ level of significance. The results show that majority of the respondents were males $(61.1 \%)$, married $(68.8 \%)$ and have tertiary education $(59.1 \%)$. Majority $(50.5 \%)$ of the respondents were between the ages of 31-45years. Socio-economic characteristics such as age, region, sex, educational level, household size and income had no significant relationship with the respondent's level of involvement in small scale poultry farming $(P<0.05)$. Results on level of involvement shows that most $(48.8 \%)$ of the sampled correspondents were involved in boilers production. The study also shows that the benefit derived in poultry farming remained the same regardless of the level of involvement of the farmers in various poultry activities, with $r$ value $(0.177), p$-value $(0.089)$ indicating that the relationship is not significant $(P<0.01)$, it also indicated that the relationship between the constraints facing the respondents and their level of involvement is not significant with $r-$ value (0.154). Also, the major constraints facing the respondents included difficulty in accessing loan and quality feed. Government should therefore make loan facilities at affordable interest rate while all the stake holders should work together to improve farmers' access to quality feed, vaccine, technical know-how and adequate extension workers.
\end{abstract}

KEYWORDS: Involvement, Small-scale, Poultry, Farming

\section{INTRODUCTION}

Small scale poultry production is an important agricultural sector usually found in most of the rural communities in Africa and most of them scavenge on available local feed resources. Although smallholder chicken production plays a major role in poverty alleviation and food security at household level. They are usually neglected in the development themes, but nowadays many researchers and development agents are making a strong consensus about their importance and contribution (Oladunni \& Fatuase, 2014).
The importance of livestock goes beyond food production (Birthal et al., 2002) it provide draught power and organic manure to crops sector and raw materials for the industrial sector. Livestock sector also make significant contribution towards supplement income from crop production and other sources and absorb financial stress due to crop failure. It generates a continuous stream of income and employment and reduces seasonality in livehood pattern of the rural dwellers (Birthal and Ali, 2005).

An important sector of the Nigerian population is the rural area. This sector is very vital to the socio-economic

Ogunwale O. G., Department of Agricultural Extension and Management, Federal College of Forestry, Ibadan.

Abegunrin O. O., Department of Agricultural Extension and Management, Federal College of Forestry, Ibadan.

Oyewole O. O., Department of Agricultural Extension and Management, Federal College of Forestry, Ibadan.

Olatunji B. T., Forestry Research Institute of Nigeria Ibadan

Ajanaku A. O., Department of Agricultural Extension and Management, Federal College of Forestry, Ibadan. 
development of the nation (Nyagba, 2009). Abah, ( 2010) also attested that rural dwellers have been found engaged in primarily economic activities that form a foundation for the country economic development. Rural areas in developing countries are usually deprived of the basic needs of life such as housing, medical care postal communication education, transport among other things. In recent years, the level of production from small scale to large scale has been observed to be decreasing, therefore the need to examine constraint limiting the level of poultry production. This study was carried out to assess the involvement, ascertain the benefits and constraints of rural dwellers of Oluyole Local Government in small scale poultry farming.

\section{RESEARCH METHODOLOGY}

The study was carried out in Oluyole Local Government Area of Oyo State. It shares boundary with Ibadan South East, Ibadan South West, Ido and OnaAra Local Government areas within Ibadan Metropolis. In the hinterland, it also boards Ogun state via Obafemi,

\section{Result and Discussion}

Table 1. Socio-economic characteristics of respondents

\begin{tabular}{lll}
\hline Variable & Frequency $(\mathrm{N}=93)$ & Percentage $(\%)$ \\
\hline Gender & 55 & 61.1 \\
Male & 37 & 39.9 \\
Female & & \\
Marital status & 14 & 15.1 \\
Single & 64 & 68.8 \\
Married & 5 & 5.4 \\
Divorced & 10 & 10.7 \\
Widowed & & \\
Educational level & 7 & 7.5 \\
No formal education & 9 & 9.7 \\
Primary education & 22 & 23.7 \\
Secondary education & 55 & 59.1 \\
Tertiary education & & \\
\hline
\end{tabular}

Table 1 shows some of the socio-economic characteristics of the respondents. The results revealed that majority $(61.1 \%)$ of the respondents were males and married (68.8\%). This signifies that married and males are more involve in poultry farming than females. The table also shows that the respondents were well
Owode, Odeda, and ljebu North Local Government respectively.

The target population for the study was rural dwellers in the selected wards of Oluyole local government. There are 10 wards in the local government out of which three were randomly selected from its rural settlements with two villages selected from each of the three wards. Not fewer than thirty small scale poultry farmers were randomly selected from each village to make a total of 95 respondents for the study.

Data were collected using a structured questionnaire administered to the respondents while interview was used to get information from the non-literate respondents. However only 93 questionnaires were retrieved. Data collected were analyzed using simple descriptive statistics while the inferential statistical tool was used for the hypothesis.

$\mathrm{H}_{0} 1$ : Chi square was used

$\mathrm{H}_{0}$ 2: Pearson product method of correlation (PPMC) was used. read as not fewer than $59.1 \%$ have tertiary education. This will give hope of their ability to access information that can help them to build up their farming enterprise. This agrees with the submission of Oyelami et al., (2017) and Okeke et al., (2018) 


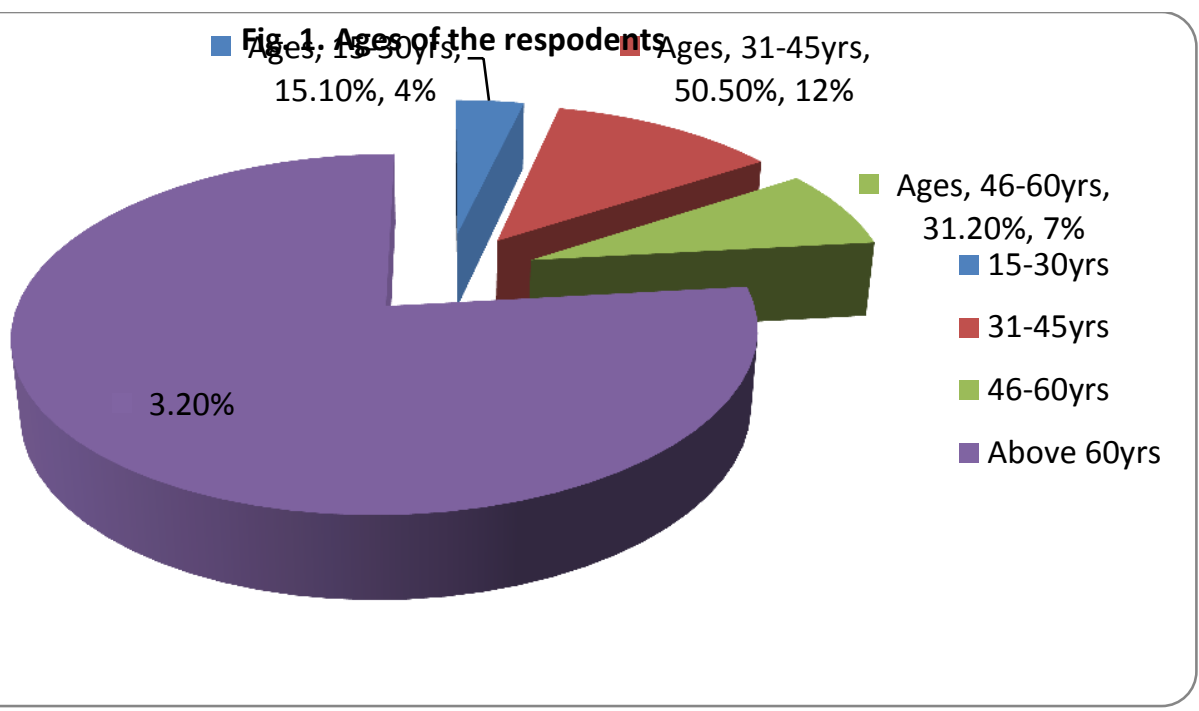

The result in figure 1 shows that majority $(50.5 \%)$ was between the ages of $31-45 y e a r s$ and only $3.2 \%$ of the respondents were above 60years of age. This shows that respondents involve in the poultry farming in the study area are in their active ages when the strength as well as energy to work is readily available. This corroborates the findings of past studies (Adisa and Akinkunmi, 2012; Gingras et al., 2008, Okeke et al., 2018; Oyelami and Ajanaku 2019) who reported that younger people are more involved in livestock farming than aged people. This implies that the younger the farmers the better the productivity.

Table 2. Level of Involvement of Respondents in small scale poultry farming

\begin{tabular}{llll}
\hline Level & Not Involved & Involved & Highly Involved \\
\hline Egg setting & $82(88.2)$ & $6(6.5)$ & $5(5.4)$ \\
Hatchery and sale & $77(82.8)$ & $10(10.8)$ & $6(6.5)$ \\
Brooding and sale & $36(38.7)$ & $32(34.4)$ & $24(25.8)$ \\
Brooding and rearing & $18(19.4)$ & $31(33.3)$ & $44(47.3)$ \\
Brooding and production & $29(31.2)$ & $19(20.4)$ & $45(48.4)$ \\
Layers production & $53(57.0)$ & $7(7.5)$ & $33(35.5)$ \\
Breeders production & $80(86.0)$ & $8(8.6)$ & $5(5.4)$ \\
Cockerel production & $71(76.3)$ & $11(11.8)$ & $10(10.8)$ \\
Point of lay sale & $67(72.0)$ & $18(19.4)$ & $8(8.6)$ \\
Artificial insemination & $86(92.5)$ & $4(4.3)$ & $3(3.2)$ \\
Feed evaluation & $50(53.8)$ & $31(33.3)$ & $12(12.9)$ \\
Feed milling & $69(74.2)$ & $15(16.1)$ & $9(9.7)$ \\
Disease management & $18(19.4)$ & $64(68.8)$ & $11(11.8)$ \\
Egg grading & $46(49.5)$ & $16(17.2)$ & $31(33.3)$ \\
Anti-mortem practice & $81(87.1)$ & $9(9.7)$ & $3(3.2)$ \\
Post mortem practice & $80(86.0)$ & $9(9.7)$ & $4(4.3)$ \\
Biogas production & $86(92.5)$ & $7(7.5)$ & $0(0.0)$ \\
Bio-security & $52(55.9)$ & $37(39.8)$ & $4(4.3)$ \\
Processing and packing & $81(87.1)$ & $8(8.6)$ & $4(4.3)$ \\
\hline
\end{tabular}

Table 2 shows the respondents level of involvement in poultry farming. The results show that majority (68.8\%) of the respondents were involved in disease management while majority $(48.8 \%)$ of the respondents were highly involved in broilers production. This may be so due to the fact that broilers are fast moving poultry product in the study area. This finding agrees with Oladunni and Fatuase (2014) who reported that most of their respondents in a similar research kept broilers but disagrees with that of Adisa and Akinkunmi (2012) in their study on women involvement in poultry production in Oyo State that shows that most of the respondents involved in keeping layer. Since most of the respondents were reported to be male this may imply that men may prefer poultry aspect that brings quick profits at short interval to meet their family needs. 
Table 3. Constraints facing the respondents on small scale farming in the study area

\begin{tabular}{llccc}
\hline Constraints & Major constraint & Minor constraint & Not a constraint & Rank \\
\hline Disease outbreak & $21(22.6)$ & $56(60.2)$ & $16(17.2)$ & $4^{\text {th }}$ \\
High cost of drugs & $18(19.4)$ & $65(69.9)$ & $10(10.8)$ & $3^{\text {rd }}$ \\
Inadequate Loan facility & $61(65.6)$ & $21(22.6)$ & $11(11.8)$ & $2^{\text {nd }}$ \\
Poor access to livestock feed & $12(12.9)$ & $21(22.6)$ & $60(64.5)$ & $8^{\text {th }}$ \\
Inadequate labour & $24(25.5)$ & $27(29.0)$ & $42(45.2)$ & $7^{\text {th }}$ \\
Insufficient land & $11(11.8)$ & $16(17.2)$ & $66(71.2)$ & $11^{\text {th }}$ \\
Availability of healthy & & & & \\
Day old chicks & $14(15.1)$ & $15(16.1)$ & $64\left(68.89^{\text {th }}\right.$ & $1^{\text {st }}$ \\
High cost of feed & $69(74.2)$ & $18(19.4)$ & $6(6.5)$ & $5^{\text {th }}$ \\
High rate of mortality & $17(18.3)$ & $60(64.5)$ & $16(17.2)$ & $10^{\text {th }}$ \\
Waste management & $5(5.4)$ & $16(17.2)$ & $72(77.4)$ & $6^{\text {th }}$ \\
Weather problems & $11(11.8)$ & $61(65.6)$ & $21(22.6)$ & \\
\hline
\end{tabular}

Table 3 shows the constraints facing the respondents on small scale farming in the study area. Among the constraints considered high cost of feed was the major constraint faced by the majority $(74.2 \%)$ of the respondents followed by inadequate loan facility (65.6). Waste management was however considered as not a constraint by the majority $(77.4 \%)$. This is possibly because feed constitutes the most expensive aspect of poultry production. This is in line with earlier reports (Okeke et al., 2018, Oyelami and Ajanaku, 2019) that finance is one of the major constraints of livestock farmers in the rural area.

Table 4. Benefits of Poultry farming to the Respondents

\begin{tabular}{llllll}
\hline Statement & SD & $\mathrm{D}$ & $\mathrm{U}$ & $\mathrm{A}$ & $\mathrm{SA}$ \\
\hline As Source of income & $3(3.2)$ & $1(1.1)$ & $0(0.0)$ & $12(12.9)$ & $77(82.8)$ \\
As Source of meat & $2(2.2)$ & $0(0.0)$ & $2(2.2)$ & $18(19.4)$ & $71(76.3)$ \\
As Source of manure & $1(1.1)$ & $2(2.2)$ & $1(1.1)$ & $47(50.5)$ & $42(45.2)$ \\
As Source of food & $3(3.2)$ & $0(0.0)$ & $0(0.0)$ & $32(34.4)$ & $58(62.4)$ \\
As Source Employment & $3(3.2)$ & $2(2.2)$ & $0(0.0)$ & $43(46.20$ & $45(48.4)$ \\
As Source of protein & $2(2.2)$ & $1(1.1)$ & $0(0.0)$ & $36(38.7)$ & $54(58.1)$ \\
Job satisfaction & $2(2.20$ & $0(0.0)$ & $0(0.0)$ & $52(55.9)$ & $39(41.9)$ \\
Raw materials & $4(4.3)$ & $5(5.4)$ & $2(2.2)$ & $55(59.1)$ & $27(29.0)$ \\
Job security & $4(4.3)$ & $4(4.3)$ & $3(3.2)$ & $45(48.4)$ & $37(39.8)$ \\
\hline
\end{tabular}

Table 4: The result shows that the majority (82.8\%) of the respondents strongly agrees that poultry serves as source of income, $76.3 \%$ strongly agrees it is a source of meat, $62.4 \%$ strongly agrees that poultry is a source of food, $48.4 \%$ strongly agrees that poultry is a source of employment, Not fewer than $97.8 \%$ of the respondents agrees that they derived job satisfaction in poultry farming.

Table 5: Cross tabulation of personal characteristics of the respondents and their level of involvement in small scale poultry farming.

\begin{tabular}{lcll}
\hline Variable & $\mathrm{X}^{2}$-Value & P-Value & Decision \\
\hline Age & 8.116 & 0.230 & NS \\
Sex & 1.953 & 0.744 & NS \\
Education & 9.618 & 0.142 & NS \\
Household size & 7.199 & 0.303 & NS \\
Income & 12.150 & 0.434 & \\
\hline
\end{tabular}

$\mathrm{S}-$ Significant at $0.05, \mathrm{NS}-$ Not significant at 0.05

Table 5 shows no significant relationship between the socioeconomic characteristics (age, sex, education level, household size, monthly income) of the respondents and their level of involvement in small scale-poultry farming. The results of hypothesis showed non-significant $(p>0.05)$ relationship between age $(x 2=8.116, p=0.230)$, gender $(x 2=1.953$, $p=0.744)$, education level $(x 2=9.618, p=0.142)$, household size $(x 2=7.199, \quad p=0.303)$ and income sources $(x 2=12.150$, $\mathrm{p}=0.434$ ). This implies that age, education level, sex, household size and income sources had no influence on the level of involvement of rural dwellers in small scale production. This report is however contrary to the submission of Oyelami and Ajanaku (2019) the reported significant relationship between selected socio economic characteristics and respondents' involvement in livestock farming. 
Table 6. Pearson product moment correlation (PPMC) analysis of benefit derived in poultry farming by the respondents and their level of involvement

\begin{tabular}{|c|c|c|c|}
\hline VARIABLE & R-value & P-VALUE & DECISION \\
\hline Benefits and Involvement 0.177 & & 0.089 & NS \\
\hline
\end{tabular}

NS - Not Significant at $p<0.05$.

The table above shows that there is no significant relationship between benefits and level of involvement $(r=0.177, p=0.089)$. However, this relationship is a positive relationship which implies that whether they are involved in poultry farming or not the benefits that can be obtained from poultry farming remains the same.

Table 7. Pearson product moment correlation (PPMC) analysis of constraints in poultry farming by the respondents and their level of involvement

\begin{tabular}{|c|c|c|c|}
\hline Variable & R-Value & P-Value & Decision \\
\hline Benefits and Involvement & 0.177 & 0.154 & NS \\
\hline
\end{tabular}

$\mathrm{S}$ - Significant at $<0.05$

Table 7 shows that there is no significant relationship, $(r=-$ $0.149, p=0.154$ ) between constraints faced in poultry farming by the respondents and their level of involvement. However, the relationship is negative which implies that through the relationship is not significant, the greater level of involvement the lower the constraint faced by the respondent. This differs from the submission of Oyelami and Ajanaku (2019) that observed significant relationship between constraints and involvement of the youth in livestock farming. This may occur as the result of the aspect of livestock been considered (poultry) which is the most prominent among the livestock farming in most of the communities.

\section{CONCLUSION AND RECOMMENDATIONS}

Based on the findings of this study, the following conclusions were drawn: the socio-economic characteristics of the respondents doesn't affect the level of involvement of respondents in the study area but the benefit derived in poultry farming remains the same regardless of the level of their involvement. However, the more the respondents that were involve in poultry farming the lower the constraints the farmers are likely going to faced which is indicated by a negative $r$ value. Also one of the major constraints facing the respondents is difficulty in loan procurement which has been hindering the growth and advancement of small scale poultry faming in the area under study and this may one of the reasons why fewer individuals were involved in poultry activities.

Poultry rearing makes an important contribution to livelihood and this can increase the total level of meat and protein production if farmers are empowered. Based on the findings of this study it is obvious that Government needs to make loan facilities at a single digit interest rate available to the small scale poultry farmers in the study area. Moreover, all the stake holders should work together improve farmers' access to quality feed, vaccine, technical know-how and adequate extension workers as this will improve their involvement and output in poultry farming.

\section{REFERENCES}

Adisa B. O. and Akinkunmi J. A., 2012. Assessing Participation of Women in Poultry Production as A Sustainable Livelihood Choice in Oyo State, Nigeria. International Journal of Plant, Animal and Environmental Sciences, Available online at www.ijpaes.com 2(2):73-82.

Birthal P. S., Joshi P. K and Kumar A., 2002. Assessment of research priorities for livestock sector in India, policy paper 15 , national centre for Agricultural Economics and Policy Research New Delhi
Birthal P. S and Ali J. 2005. Potential of livestock sector in rural transformation , In: Rural Transformation in India; The role of Non-farm sector (Rohini Nayyar and distribution New Delhi)

Gingras, Y., Larviere, V., Maceluso, B. and Robitaile, J. P., 2008. The effect of ageing on researchers. PLoS ONE 3(12): e4048. https://doi.org/10.1371/journal.pone.0004048.

National Population Census, 2006. Legal Notice on Publication of the 2006 Census Report. Extraordinary Federal Government of Nigeria Official gazette No. Pp: 47-53.

Nyagba, S., 2009. "Review of Nigerian's Rural development policy for sustainable Development " Paper presented at Business Round Table at Abuja, 9-11 July.

Okeke E. N., Oloba O. G., and Oyelami B. A., 2018. Rural Dwellers' Involvement in Livestock Farming in Egbeda Local Government Area of Oyo State. International Journal of Environment, Agriculture and Biotechnology. Vol. 3, Issue 3, Pp 2250-2257. Published by IJEAB, https://dx.doi.org/10.22161/ijeab/3.6.41 ISSN: 2456-1878 www.ijeab.com

Oladunni, M. E. and Fatuase, A. I., 2014. Economic Analysis of Backyard Poultry Farming in Akoko North West Local Government Area of Ondo State, Nigeria. Global Journal of Biology, Agriculture and Health Sciences. 3(1): 141-147.

Oyelami B. A., O. Eniola, B. Osikabor, O. O. Abegunrin, O. G. Ogunwale and Adeyanju O., 2017. Assessment of rural dwellers' involvement in livestock farming as a means of livelihood in Afijio local government area of Oyo state. Nigerian Journal of Animal Production. Published by The Nigerian Society for Animal Production. Vol. 44:2 pp68-78.

Oyelami, B. A. and Ajanaku, A. O., 2019. Assessment of Youth Involvement in Livestock Farming as a Career in Oluyole Local Government, Ibadan. International Journal of Forest, Animal and Fisheries Research (IJFAF) [Vol-3, Issue-4, JulAug, 2019] ISSN: 2456-8791 https://dx.doi.org/10.22161/ijfaf.3.4 